\title{
A RARE CASE OF MELANOMA OF THE RECTUM HEMORRHOID NODULE
}

\author{
Vladimir Selakovic1, Milan Ranisavljevic1,2, Tijana Vasiljevic 2,3, Bratislav Stoiljkovic3, Biljana Kukic ${ }^{2,4}$ \\ IOncology Institute of Vojvodina, Department for Operative Oncology, Novi Sad, Serbia \\ 2 Medical Faculty, University of Novi Sad, Novi Sad, Serbia \\ ${ }^{3}$ Oncology Institute of Vojvodina, Department for Pathology Novi Sad, Serbia \\ ${ }^{4}$ Oncology Institute of Vojvodina, Department for Internal Oncology, Novi Sad, Serbia
}

\section{PRIKAZ SLUČAJA MELANOMA REKTUMA U HEMOROIDU}

\author{
Vladimir Selaković1, Milan Ranisavljević1,2, Tijana Vasiljević2,3, Bratislav Stoiljković3 , Biljana Kukić2,4 \\ IInstitut za onkologiju Vojvodine, Klinika za operativnu onkologiju, Novi Sad \\ ${ }^{2}$ Medicinski fakultet, Univerzitet u Novom Sadu, Novi Sad \\ ${ }^{3}$ Institut za onkologiju Vojvodine, Zavod za patologiju, Novi Sad \\ ${ }^{4}$ Institut za onkologiju Vojvodine, Klinika za internu onkologiju, Novi Sad
}

\begin{abstract}
Anorectal melanoma $(A M)$ is an aggressive and very rare malignancy. The aim of this case report is to present a case of anorectal melanoma that occured in hemorrhoidal node after a colorectal surgery.

A patient aged 69 years was treated at the Oncology Institute of Vojvodina for histopathological (HP) verified melanoma of the anorectum (S100, HMB45 and Melan A positive) localized in the hemorrhoidal node. Wide local excision was made. Three months after the operation secondary deposits ocurred at the site of the colorectal anasthomosis, stomach, lung and brain. Polymerase chain reaction analysis of tumor DNA found no mutation in the BRAF V600 gene. Five months after the operation the patient is still alive and on supportive and symptomatic therapy.

Despite its rarity, AM should always be considered in unusual anorectal lesions first at all in hemorrhoid nodules.
\end{abstract}

Key words: melanoma; rectum; haemorrhoids.

\section{INTRODUCTION}

Anorectal melanoma (AM) is an aggressive and rare malignancy ( 1.7 cases per 1 million), despite the fact that anorectum is the third most common mucosal site for melanoma (1-3). Many authors have published multiple isolated case reports, but clinical management strategies do not exist because of the lack of randomized clinical trials and its rarity.

Histological subtypes of AM are as follows: $44 \%$ epitheloid, 31\% mixed type, and 25\% spindle cell melanoma (4-6). Yap and Neary categorize AMs in the following way: anal - if situated below the dentate line, rectal - if located above the dentate line, and anorectal- if located around the dentate line (7).

The aim of this case report is to present a rare case of anorectal melanoma that occured in hemorrhoid node after a colorectal surgery at the Oncology Institute of Vojvodina.

\section{SA ŽETAK}

Anorektalni melanom je agresivan i redak tumor. Cilj ovog prikaza slučaja bio je da se predstavi izuzetno redak slučaj anorektalnog melanoma lokalizovanog $u$ hemoroidu.

Pacijentkija stara 69 godina lečena je na Institutu za onkologiju Vojvodine zbog patohistološki verifikovanog melanoma anorektuma (S100, HMB45 I Melan A pozitivan) lokalizovanog $u$ hemoroidu. Operativno lečenje sastojalo se od široke lokalne ekscizije. Tri meseca nakon operacije dolazi do razvoja sekundarnih depozita na mestu kolorektalne anastomoze, u želucu, plućima i mozgu. Analizom tumorske DNK polimeraza lančanom reakcijom nije pronađena mutacija BRAF V600 gena. Pet meseci nakon operacije pacijentkinja je živa i na suporativnoj i simptomatskoj terapiji.

Uprkos malom broju slučajeva, uvek treba razmišljati o anorektalnom melanomu kod nespecifičnih anorektalnih lezija, prvenstveno hemoroida.

Ključne reči: melanom; rektum; hemoroidi.

\section{CASE REPORT}

Patient aged 69 years was treated at Oncology Institute of Vojvodina for histopathological (HP) verified melanoma of the anorectum in the period from $29^{\text {th }}$ September to $1^{\text {st }}$ October 2020.

Initial colonoscopy of the patient was done on $24^{\text {th }}$ May 2019 where 15 centimeters $(\mathrm{cm})$ from the anocutaneous line (ACL) exophytic (saddle shaped) tumor with broad base was seen, about $5 \mathrm{~cm}$ in diameter that almost completely closed the intestinal lumen. HP analysis confirmed well differentiated adenocarcinoma of the colon. Magnetic resonance imaging (MRI) of the pelvis was performed on $27^{\text {th }}$ October 2019 and it described the tumor (dimensions $3 \times 2.9 \times 2.7 \mathrm{~cm}$ ) at the initial part of sigmoid colon which completely filled the intestinal lumen and highly infiltrated the muscular layer of the anterior and right lateral wall with rare oval lymph nodes in mesocolon. Computed tomography (CT) scans of the chest and abdomen were without dissemination of the primary disease. 
Operative treatment was performed on August 202019 when an anterior high resection of the rectum was performed with the creation of termino-terminal anasthomosis using double stapling technique. HP analysis of specimen was adenocarcinoma at tubulovilous adenoma (low grade), without metastases in lymph nodes $(0 / 12)$. TNM classification at the moment of operation was pT1N0M0. The operative and postoperative course passed without complications and the patient was discharged for further home treatment on the 6th postoperative day. A multidisciplinary team after the operation indicated regular follow-up by the surgeon and an oncology internist.

The patient was very well until July 2020, when she come to the surgeon with the history of bleeding per rectum. Control imaging finding (abdominal and thorax
CT performed on June 2020) was without the sings of metastases. Control colonoscopy from 20/06/2020 described intact colorectal anasthomosis without sings of local recurrence and/or rest of the tumor. One thrombosishemorrhoid nodule above the ACL was described. The surgeon performed digitorectal examination and his finding was that patient hasthrombosis hemorrhoid at the fingertips behind the ACL and the patient was suggested surgical treatment (hemorrhoidectomy) due to the pain in the rectum during the examination as well as the presence of a larger amount of fresh blood in the stool.

The patient underwent a hemorrhoidectomy in a private health institution (July 24, 2020). The finding from HP analysis of the specimen spoke in favor of partially ulcerated melanoma of the anorectal mucosa (invasion

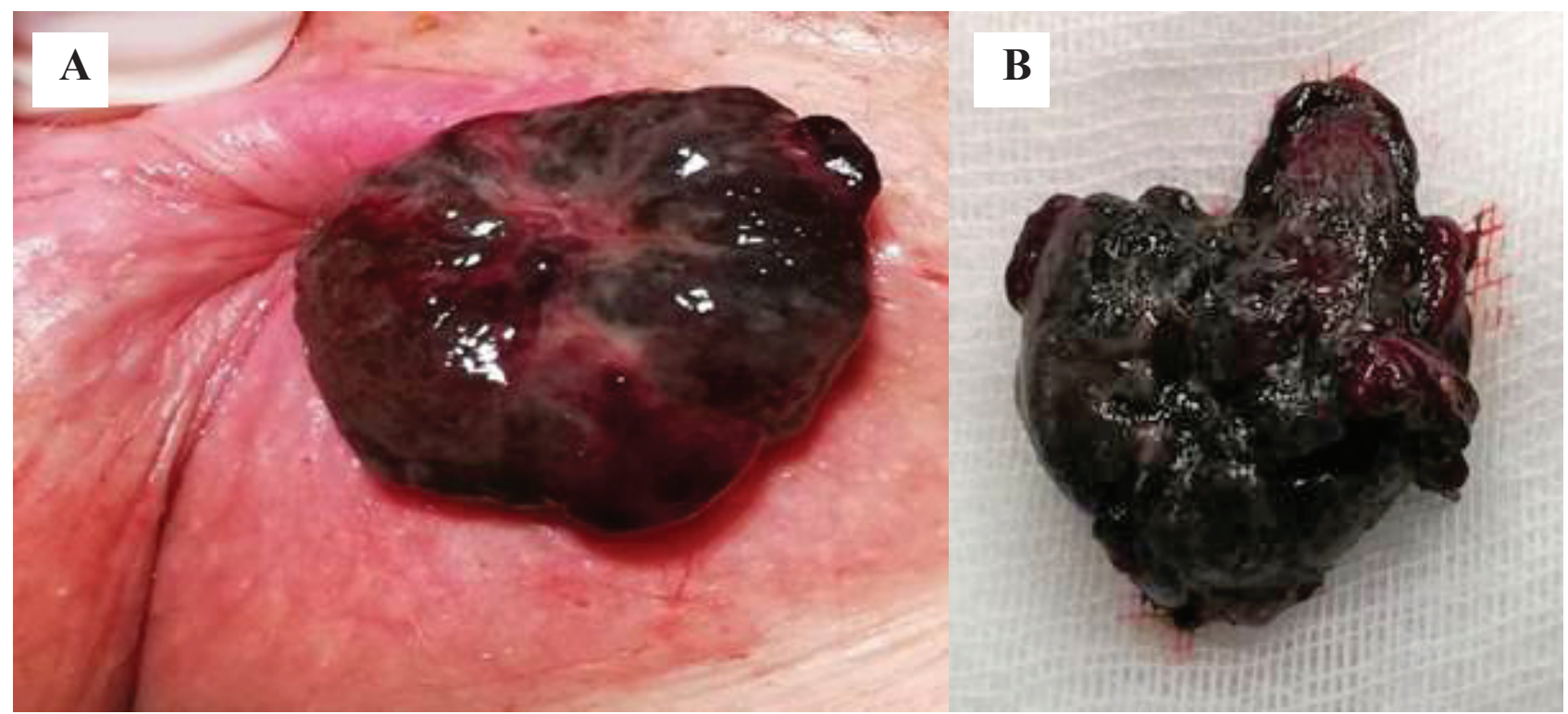

Figure 1. Macroscopic findings. A-tumor prolapsed trough rectum; B-Surgical specimen

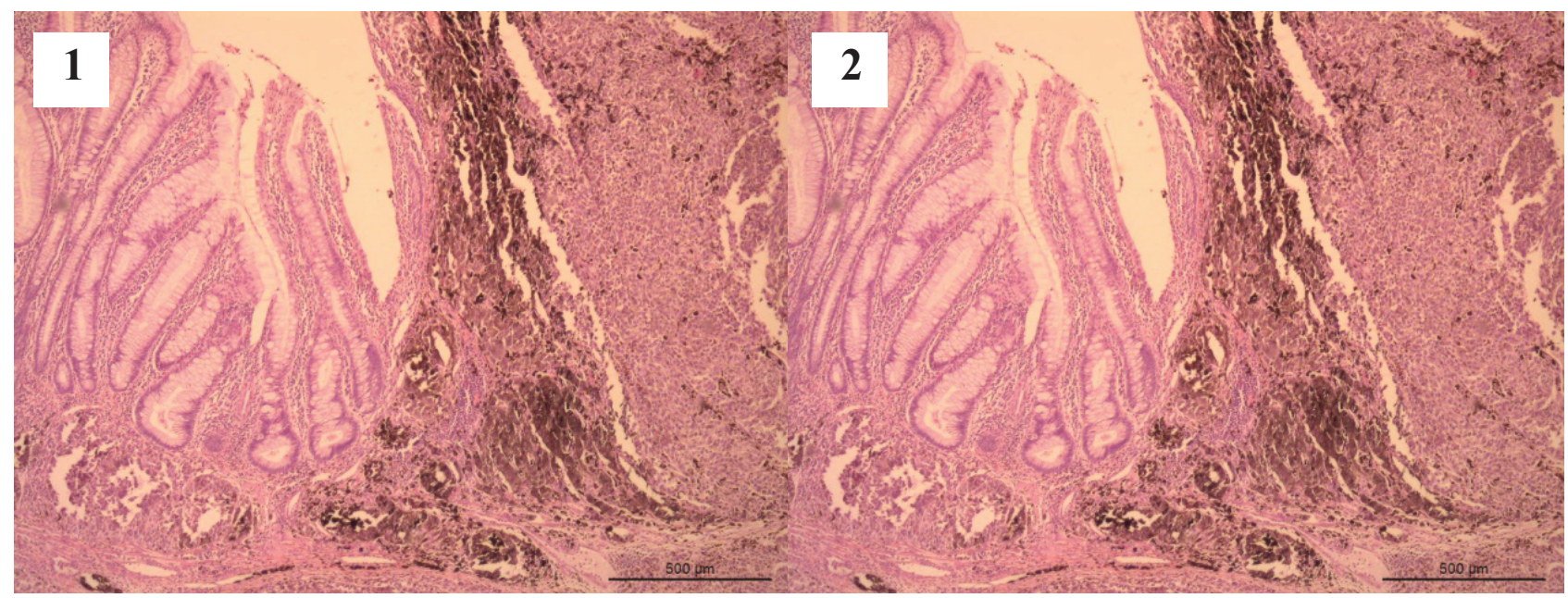

Figure 2. Microscopic findings. 1 - Histopathological analysis of the tumor showed nested spindle-shaped melanocites with melanin rich cytoplasm (hematoxylin-eosin staining $x$ 50); 2 - Immunohistochemistry confirmed melanocytic nature of tumor cells, Melan A+ (immunohistochemical staining x 50). 
depth of up to 5 millimeters (mm)). Immunohistochemical analysis registered tumor cells that are S100, HMB45 and Melan A positive, which confirmed the HP diagnosis.

After the operative treatment, the patient contacted the surgeon at the Vojvodina Institute of Oncology (September 4, 2020) and still complained about the bleeding from the rectum. Digitorectal examination revealed a rest of the tumor localized at $8 \mathrm{~h}$ which is darker stained and prolapsed through the rectum. A reoperation was performed 30th September 2020. when a local excision was made and HP analysis confirmed the diagnosis of exulcerated and infiltrative melanoma. After the discharge, the patient was clinically monitored by a surgeon and an oncology internist and was without any problems for some period.

Macroscopic and microscopic findings are shown on Figures 1 and 2.

Three months after the reoperation, the patient came to the surgeon due to profuse bleeding from the anus, haemathemesis and general weakness. Digitorectal examination was without sings of local relapses, so the surgeon requested to for colonoscopy, gastroscopy, as well as CT scans of the pelvis, abdomen, chest and head to be performed.

Gastroscopy and colonoscopy were performed (December 2, 2020) - the findings of gastroscopy indicated at least 5 darker pigmented ulcerations up to 15 $\mathrm{mm}$ in diameter localized on the funds, currently without signs of active bleeding. Two polypoid changes with a diameter of about 20 and $30 \mathrm{~mm}$ were identified colonoscopically in the area of the anasthomosis from colorectal surgery (with the same characteristics like in the stomach). The HP findings indicated that they were melanoma metastases. Polymerase chain reaction analysis of tumor DNA found no mutation in the BRAF V600 gene. Imaging diagnostics were performed on January 6, 2021. CT scans indicated a high number of newly formed secondary deposits (the largest $25 \mathrm{~mm}$ in size) in lungs. In abdomen, there were at least 4 nodular thickenings of the gastric wall localized in the fundus region with endoluminal propagation. CT of the small pelvis showed significant wall thickening in the anastomotic region with multiple regional lymph nodes. In head, there were at least 7 hyper dense changes with vasogenic perifocal edema (secondary deposits) localized in the frontal, parietal and occipital cortex.

Patient is still alive (five months after the operation) and he is on supportive and symptomatic therapy.

\section{DISCUSSION}

Tumor thickness of more than $4 \mathrm{~mm}$ (Breslow classification) is associated with more aggressive disease forms in cases of cutaneous melanoma, but in cases of AM the data are inconsistent (4). The 5-year disease-specific survival (DSS) is $<10 \%$ and the mean survival time is 12 18 months in cases of AM.

Anal melanoma occurs mostly among females of older age ( $\leq 55$ years). Clinical presentation of the disease is primarily hematochezia (primary symptom), pain and anal mass. Anal melanoma is mostly located around the ACL, including the ACL and the anal canal (4-6).

Zhang et al reported 216 cases of AM and concluded that AM was more likely to be clinicaly benign. The maximum diameter of the tumor was relatively small; $43.6 \%$ were polypoid and only $23.6 \%$ of the tumors were invading the surrounding tissues. Many such tumors produce melanin $(70-80 \%)(8)$.

One additional problem with AM diagnosis is that a high number of tumors (20-30\%) is amelanotic and no publication has compared pigmented with amelanotic lesions due to the small number of cases. In the study from Hillenbrand it is highlighted that "while not every dark anorectal swelling is a malignant melanoma, not every malignant melanoma is pigmented" and immunohistochemical staining can be very useful in diagnosing questionable lesions. Melanoma is positive for S-100 protein, HMB-45 and vimentin. It is negative for CEA, cytokeratin, and epithelial membrane antigen $(3,4$, $6,9,10)$.

The appropriate evaluation of AM is minimally detailed in the literature, but opinion is to make CT scanning of the head, chest, abdomen, and pelvis $(6,10)$. PET scanning can be reserved for lesions of indeterminate nature on the CT scan, because its sensitivity tends to be low otherwise (11). Endoluminal ultrasound and magnetic resonance imaging could be useful when evaluating the degree of rectal sphincter involvement and making operative treatment decision (12). The value of endoscopy in visualizing and sampling AM is obvious, and recent publications have described endoscopic therapeutic approaches (13).

Despite the fact that AM is a rare tumor with poor diagnosis, patients are commonly misdiagnosed as heaving haemorrhoids, like in our case, which is not an isolated case (14-16). The early symptoms of AM resemble some anorectal benign diseases, such as thrombosis hemorrhoids, mixed hemorrhoids and rectal adenomas. In the advanced stage, AM is similar to rectal cancer. Better prognosis for AM is given when the tumor is located in the mucosa and submucosa, and in such cases the tumor can be treated by wide local excision (WLE) and in other cases with abdominoperineal amputation (APR) (17).

$\mathrm{AM}$ is not sensitive to radiotherapy/chemotherapy and surgical excision remains the only possible therapeutic treatment. Data from different studies show no difference in long-term survival and overall quality of life (2, 5-7, 13, 
17). In analysis from Yeh et al. who has compared APR and WLE, the rates of local recurrence were 21\% (APR) and $26 \%$ (WLE) and the disease specific survival was $34 \%$ and $35 \%$, respectively with no statistical differences. Conclusion of the study was that the range of surgical excision was not correlated with the prognosis (2).

In our cases we have decided to make WLE because it has many advantages such as minor surgical trauma, quick recovery, less effect on the function of the intestinal tract and preservation of anal function. Our opinion is that WLE should be the first choice of treatment, and APR can be performed when WLE is impossible, when the surgical margins of the specimen are positive, or in the cases of tumor recurrence.

Biotherapy and chemotherapy are necessary postoperative procedures, while AM is highly invasive and metastases in lymph nodes or/and distal metastases may occur. Cisplatin, catharanthine, or dacarbazine combined with immunomodulators (interleukin-2 and interleukin- $\alpha$ ) can improve the survival status of some patients (18).

In patients with positive lymph nodal status and distand metastases, $\alpha$-interferon and Interleukin-2 (IL-2) have demonstrated a significant prolongation of relapsefree-survival and overall survival, but with expressed systematic side effects (haematological, autoimmune and neuropsychiatric disorders) (19).

Novel immunotherapeutic strategies for metastasis are having promising results and they are focused on immune checkpoints. The patients with KIT-mutated metastatic melanomas are amenable to single-agent therapy with one of the kit inhibitors imatinib, dasatinib, sunitinib or sorafenib (20).

Dabrafenib, vemurafenib and encorafenib are classified as reversible ATP-competitive inhibithors with selective inhibition on BRAF, MEK and MAP genes. In approximately $50-70 \%$ of patients with mutation in BRAF V600E or in V600K, these medications have demonstrated their efficacy (21). Studying mutations in melanoma may allow finding new target molecules to develop specific treatments with better response. At melanomas with the absence of BRAF V 600 mutation, the treatment of choice in advanced, refractory forms is based on the use of ipilimumab, alone or in combination with standard chemotherapy (21).

Melanoma is a highly angiogenic tumor and in some cases the antiangiogenetic treatment (bevacizumab combined with nab-paclitaxel) has been proven to be a potential strategy (22).

Despite its rarity, AM should always be considered in unusual anorectal lesions, first at all in hemorrhoid nodule. First line surgical method should be WLE, while in cases of local relapses APR.

\section{REFERENCES}

1. Weinstock MA. Epidemiology and prognosis of anorectal melanoma. Gastroenterology 1993; 104: 174-8.

2. Yeh JJ, Shia J, Hwu WJ, et al. The role of abdominoperineal resection as surgical therapy for anorectal melanoma. Ann Surg 2006; 244: 1012-7.

3. Kohli S, Narang S, Singhal A, Kumar V, Kaur O, Chandoke R. Malignant melanoma of the rectum. J Clin Imaging Sci 2014; 4: 4.

4. Kobakova I, Stoyanov G, Popov H, et al. Anorectal melanoma - a histopathological case report and a review of the literature. Folia Med (Plovdiv) 2018; 60: 641-6.

5. Atak I. Anorectal malignant melanoma: retrospective analysis of six patients and review of the literature. Prague Med Rep 2018; 119: 97-106.

6. Pantalone D, Taruffi F, Paolucci R, Liguori P, Rastrelli $\mathrm{M}$, Andreoli F. Malignant melanoma of the rectum. Eur J Surg 2000; 166: 583-4.

7. Yap LB, Neary P. A comparison of wide local excision with abdominoperineal resection in anorectal melanoma. Melanoma Res 2004; 14: 147-50.

8. Zhang S, Gao F, Chen LS, Tang ZJ, Liang JL, Wu Q. Clinical analysis of anorectal malignant melanoma. Zhonghua Weichang Waike Zazhi 2005; 8: 309-11.

9. Hillenbrand A, Barth TF, Henne-Bruns D, Formentini A. Anorectal amelanotic melanoma. Colorectal Dis 2008; 10: 612-5.

10. Nunez Herrero L, Chaucer B, Zafar W, Davalos F, Salman S, Naing S. Primary malignant melanoma of the rectum: a case report of an extremely rare gastrointestinal cancer. J Gastrointest Cancer 2016; 47 : 494-6.

11. Maubec E, Lumbroso J, Masson F, et al. F-18 fluorodeoxy-D-glucose positron emission tomography scan in the initial evaluation of patients with a primary melanoma thicker than $4 \mathrm{~mm}$. Melanoma Res 2007; 17: $147-54$.

12. Li XT, Sun YS, Tang L, Cao K, Zhang XY. Evaluating local lymph node metastasis with magnetic resonance imaging, endoluminal ultrasound and computed tomography in rectal cancer: a meta-analysis. Colorectal Dis 2015; 17: 129-35.

13. Tanaka S, Ohta T, Fujimoto T, Makino Y, Murakami I. Endoscopic mucosal resection of primary anorectal malignant melanoma: a case report. Acta Med Okayama 2008; 62: 421-4.

14. Liptrot S, Semeraro D, Ferguson A, Hurst N. Malignant melanoma of the rectum: a case report. J Med Case Rep 2009; 3: 9318. 
15. Turner G, Abbott S, Eglinton T, Wakeman C, Frizelle F. Anorectal melanoma: not a haemorrhoid. N Z Med J 2014; 127: 73-81.

16. Zhang S, Gao F, Wan D. Effect of misdiagnosis on the prognosis of anorectal malignant melanoma. J Cancer Res Clin Oncol 2010; 136: 1401-5.

17. Che X, Zhao DB, Wu YK, et al. Anorectal malignant melanomas: retrospective experience with surgical management. World J Gastroenterol 2011; 17: 534-9.

18. Joyce T, Oikonomou E, Kosmidou V, et al. A molecular signature for oncogenic BRAF in human colon cancer cells is revealed by microarray analysis. Curr Cancer Drug Targets 2012; 12: 873-98.

19. Malaguarnera G, Madeddu R, Catania VE, et al. Anorectal mucosal melanoma. Oncotarget 2018; 9: 8785-800.
20. Perfetti V, Laurini E, Aulić S, et al. Molecular and functional characterization of a new $3^{\prime}$ end KIT juxtamembrane deletion in a duodenal GIST treated with neoadjuvant imatinib. Oncotarget 2017; 8: 56158-67.

21. Ascierto PA, Minor D, Ribas A, et al. Phase II trial (BREAK-2) of the BRAF inhibitor dabrafenib (GSK2118436) in patients with metastatic melanoma. J Clin Oncol 2013; 31: 3205-11.

22. Cui C, Mao L, Chi Z, et al. A phase II, randomized, double-blind, placebo-controlled multicenter trial of Endostar in patients with metastatic melanoma. Mol Ther 2013; 21: 1456-63. 